\title{
PREVALENCE OF THE ENTEROTOXIGENIC STAPHYLOCOCCUS AUREUS STRAINS ISOLATED FROM RAW MILK AND CHEESE PRODUCED IN NORTH MACEDONIA
}

\author{
Marija Ratkova Manovska, Mirko Prodanov, Ljupcho Angelovski, \\ Dean Jankuloski, Pavle Sekulovski \\ Food Institute, Faculty of Veterinary Medicine - Skopje, \\ Ss Cyril and Methodius University in Skopje, Lazar Pop Trajkov 5-7, \\ 1000 Skopje, R. North Macedonia
}

Received 11 December 2020; Received in revised form 12 February 2021; Accepted 19 February 2021

\begin{abstract}
Staphylococcus aureus is an important foodborne pathogen due to toxin-related virulence, invasiveness and antibiotic resistance. The ability of $S$. aureus strains to produce one or more staphylococcal enterotoxins (SEs) in food has been associated with the occurrence of staphylococcal food poisoning (SFP), which is the most common foodborne intoxication worldwide. The study aimed to determine the count of $S$. aureus strains in samples of raw cow's milk and various cheeses produced in R. North Macedonia and to detect their ability to produce enterotoxins by passive agglutination SET RPLA (OXOID, UK) and by enzyme-linked fluorescence assay (ELFA) VIDAS SET 2 (Biomerieux, France). A total of 130 S. aureus strains were analyzed. The ability to produce SEs was determined in $17(13.1 \%)$ strains using the SET RPLA detection kit and in $20(15.4 \%)$ strains using the VIDAS SET 2. The study detected enterotoxigenic strains in cheese samples, despite the low count of $S$. aureus which was below the detection limit according to the Book of rules for microbiological criteria (Off. G. of R.M no 100/2013). Based on these and similar findings, S. aureus must be considered as a possible cause of intoxication, despite the undetected and underreported cases of SFP in the scientific literature.
\end{abstract}

Key words: Staphylococcus aureus, cheese, milk, enterotoxins, SET RPLA, VIDAS SET 2, North Macedonia

\section{INTRODUCTION}

Staphylococcus aureus is one of the most important causative agents of food poisoning worldwide (1). It is an important pathogen due to its combination of toxin-related virulence, invasiveness and antibiotic resistance. One of its pathogenic properties is the ability to produce one or more staphylococcal enterotoxins (SEs), which are

Corresponding author: Dr. Marija Ratkova Manovska, DVM E-mail address: ratkova.marija@fvm.ukim.edu.mk

Present address: Food Institute, Faculty of Veterinary Medicine - Skopje, Ss Cyril and Methodius University in Skopje, Lazar Pop Trajkov 5-7, 1000 Skopje, R. North Macedonia

Phone: +3892 3240736; Fax: +3892114619

Copyright: (C) 2021 Ratkova Manovska M. This is an open-access article published under the terms of the Creative Commons Attribution License which permits unrestricted use, distribution, and reproduction in any medium, provided the original author and source are credited.

Competing Interests: The authors have declared that no competing interests exist.

Available Online First: 26 February 2021

Published on: 15 March 2021

https://doi.org/10.2478/macvetrev-2021-0014 associated with the occurrence of staphylococcal food poisoning (SFP).

Staphylococcal poisoning is one of the most common forms of foodborne illness and occurs by ingestion of food that contains pepsin-resistant SEs produced by enterotoxigenic strains of coagulasepositive staphylococci (CPS), mainly $S$. aureus. According to EFSA reports, staphylococcal intoxications are responsible for $6.4 \%$ of all foodborne illnesses and are among the top four causes of food poisoning after Salmonella spp. foodborne viruses and Campylobacter spp. (2). According to the same report, staphylococcal intoxications cause a higher mortality rate $(7 \%)$ compared to foodborne viruses (2.2\%), and Campylobacter spp. (1.1\%). Recently, SFP has been reported to have a low hospitalization rate of $6.4 \%$, due to the nature of the toxins and the rarely severe symptoms, usually being underreported (3). 
To this date, twenty-one SEs or enterotoxinlike proteins have been reported (4). They are low molecular weight proteins that are classified into five main types according to their antigenic properties SEA, SEB, SEC (SEC1, SEC2, SEC3 and SEC ovine and bovine variants), SED and SEE $(4,5)$, which are thought to be responsible for $95 \%$ of all staphylococcal intoxications $(6,7,8)$. The "new types" of SEs reported in recent years are designated by the initial letters from SEG to SEV (4). SEA, which is toxic at low concentrations $(0.6 \mathrm{ng} / \mathrm{ml})$ (9), is most commonly detected in food and is also considered to be the major cause of SFP in several countries, probably because of its exceptionally high resistance to proteolytic enzymes ( $75 \%$ of outbreaks), followed by SEB, SEC (mostly associated with animal origin) SED and SEE (10).

Staphylococci in food may originate from raw materials of animal origin (e.g., milk from mastitis cows), but also from endemic strains present in the production process that may be a potential source of contamination $(11,12)$. Foods of animal origin, particularly milk and dairy products, are most commonly associated with this foodborne disease. Milk is known to be an ideal growth medium for S. aureus and its enterotoxin production, being one of the most common causes of bovine mastitis, especially subclinical mastitis (9). During the cheese production phases, S. aureus counts could exceed the expected count, therefore posing potential threat for SPF. Taking into consideration that approximately $10 \%$ of the cheese produced in Europe is from raw milk, good hygiene practices must always be maintained in production and processing facilities due to the potential risk for public health $(3,13)$. The produced SEs retain its potency for SFP even if the $S$. aureus cells are inactivated e.g. pasteurization (3).

Many strains of $S$. aureus can produce one or more enterotoxins, and the severity of the disease depends on the amount of ingested food, the SE concentration in food, and the health status of the consumer. SFP can be caused by as little as 20$100 \mathrm{ng}$ of enterotoxin. After ingestion, symptoms (copious vomiting, diarrhea, abdominal pain, or nausea) occur rapidly and abruptly (4). S. aureus is frequently present in the normal human microbiome (nose and hands 30-50\%) and can be easily transmitted to food and working surfaces by food handling personnel (14). Jablonski and Bohach (15) reported that $10^{3}$ to $10^{5} \mathrm{CFU} / \mathrm{g}$ of enterotoxigenic
S. aureus strains can produce sufficient amount of SE that would pose a health risk to consumers and cause SFP.

Several tests and methods are available to determine the ability of strains to produce SEs. In addition to traditional bacteriological methods, serological tests (reversed passive latex agglutination - RPLA) and immunoassays (enzymelinked fluorescence test - ELFA) are used. These methods require an average of 3-26 hours and are capable of detecting toxin levels in the range of $0.25-1 \mathrm{ng} / \mathrm{ml}(9)$.

Therefore, the study aimed to obtain data on the prevalence and counts of $S$. aureus strains in raw milk and cheese, and to determine the number of strains capable of producing enterotoxins by using the SET RPLA detection method by passive agglutination and VIDAS SET 2 which is an enzyme-linked fluorescence test (ELFA).

\section{MATERIAL AND METHODS}

\section{Sampling}

The raw cow milk and cheese samples were obtained from fourteen different dairies in North Macedonia between October 2017 and January 2018. One hundred and fifty-three samples of raw cow's milk were collected immediately after arrival in the dairies from various milk producers and were transported to the microbiology laboratory in $60-\mathrm{ml}$ sterile cups at $4-8{ }^{\circ} \mathrm{C}$ within 4 hours.

Seventy-five samples of different cheese types (cow's and sheep's) and twenty samples of yellow cheese, aged between 2 weeks and 2 months were collected. The cheese samples were produced from cooked milk and were collected on several occasions, at different ripening periods. The sampling was performed from commercial packaging and the storage and transportation conditions were the same as for the raw milk samples.

\section{Isolation and enumeration of S. aureus}

Samples were analyzed for enumeration of coagulase-positive staphylococci (S. aureus) using TEMPO STA cards and then strains were confirmed according to ISO 6888-1 "Horizontal method for enumeration of coagulase-positive staphylococci" (16), with additional identification using GP cards of the VITEK 2 automatic identification system (Biomerieux). 
The TEMPO system (bioMérieux, Marcyl'Étoile, France) is the first semi-automatic system detecting the number and volume of positive wells (fluorescent or non-fluorescent) in the specific test card and enumerating bacteria by utilizing statistical methods based on the most probable number (MPN). It is AFNOR certified and AOAC validated. The TEMPO system is increasingly used in the food industry due to its semi-automated, traceable, and fast process for bacteriological counting and identification without the need for additional identification tests. We used the TEMPO STA test card for each raw milk sample. The suspension of the medium containing $1 \mathrm{ml}$ of the sample was distributed in the 48 analysis wells of the test card with three different volumes $(225,22.5$ and $2.25 \mu \mathrm{l})$, from which a fluorescence signal can be recorded and interpreted to derive the initial bacterial content, expressed in CFU/ml. The TEMPO STA test card was used to determine the $S$. aureus concentration after incubation at $35{ }^{\circ} \mathrm{C}$ for $24-27 \mathrm{~h}$. After each incubation period, all cards were analyzed using the TEMPO reading station and the results were expressed in CFU/ml for the original sample after manual entry of the initial dilution factor. Taking into account that we used $1 \mathrm{ml}$ of raw milk in the initial suspension, we were able to detect $S$. aureus counts ranging from 1 to $4900 \mathrm{CFU} / \mathrm{ml}$.

The evaluation of the acceptability of raw milk regarding the presence of $S$. aureus in raw milk was carried out in accordance with Article 19 of the Book of rules on the specific requirements for safety and hygiene and the manner and procedure of carrying out official controls on milk and milk products (Official Gazette of RM no. 26/2012). Acceptable raw milk samples were considered if 2 out of 5 tested units would have $S$. aureus count between 500 and $2000 \mathrm{CFU} / \mathrm{ml}$. If only one unit exceeded count of $2000 \mathrm{CFU} / \mathrm{ml}$ (17), the raw milk sample was considered unacceptable.

According to the Book of rules for microbiological criteria of food safety Off. G. of R. M. no100/2013, we took 5 units per cheese sample to see if the criteria for enumeration of coagulasepositive staphylococci were met. Samples with a count above $1000 \mathrm{CFU} / \mathrm{g}$ were considered unacceptable (18).

\section{Detection of the SES}

Strains were obtained from the following sources: raw cow's milk $(n=108)$, various cheeses $(n=17)$, and hard yellow cheese $(n=5)$. One colony per sample was tested. We investigated the ability of $S$. aureus strains to produce enterotoxins using the reverse passive latex agglutination test SET RPLA detection kit (includes detection of SEA, SEB, SEC and SED) (Oxoid, UK). According to the manufacturer, the sensitivity of the test was $0.5 \mathrm{ng} / \mathrm{ml}$ of the tested extract, i.e. bacterial suspension. All $S$. aureus isolates were incubated in Tryptone soy broth (CM0129B, Oxoid-UK) for $12-18 \mathrm{~h}$ at $37{ }^{\circ} \mathrm{C}$. Subsequently, all broth cultures were filtered and the filtrate was used for the assay by reverse passive latex agglutination SET-RPLA (TD0900A, Oxoid-UK) according to the manufacturer's instructions.

The second test (VIDAS SET 2) was used to detect the ability of strains to produce SEs (BioMérieux SA - France). The test is an enzyme-linked fluorescence assay (ELFA) used for qualitative and semi-qualitative detection of 7 types of enterotoxins (SEA, SEB, SEC1, SEC2, SEC3, SED and SEE). The manufacturer's general protocol was modified with SET RPLA and ENTEROTOX-F (Denka Seiken Co., Ltd., Japan) extraction. The supernatant was further processed according to the manufacturer's instructions $(19,20)$.

\section{RESULTS}

In 153 raw cow milk samples, $S$. aureus was detected in 108 samples (70.6\%). The number of colonies per sample varied in a wide range (Table 1). In 56 samples (36.6\%) the bacterial count was higher than $2000 \mathrm{CFU} / \mathrm{ml}$ deeming them unacceptable according to the described criteria (17). The ability of the strains to produce SEs is shown in Table 1. A total of $10(6.5 \%)$ strains were positive by VIDAS SET 2 method, and $8(5.2 \%)$ by SET RPLA method (SEA: $n=3$, SEB: $n=1$, SEA and SEB: $n=2$, SEA and SEC: $n=1$, SEC: $n=1$ ).

From 75 samples of different types of cheese and 20 samples of hard yellow cheese $S$. aureus was found in $22(23.1 \%)$ samples. Twelve units from all cheese samples $(16 \%)$ and five units $(25 \%)$ of the hard yellow cheese samples were unsatisfactory according to the previously described criteria (18).

The ability of S. aureus strains obtained from cheese samples to produce SEs was confirmed in 10 $(10.5 \%)$ by VIDAS SET 2 and in $9(9.4 \%)$ by SET RPLA kit. The ability to produce SEC was detected in 4 strains (44.4\%), SEA in 2 (22.2), SEB in 1 and SEB with SEC in 1 strain. The data for the cheese samples are shown in Table 2. 
Table 1. Results for counts of S. aureus and SE detection from raw milk

\begin{tabular}{|c|c|c|c|c|c|c|}
\hline $\begin{array}{l}\text { No. of dairy facility } \\
\text { and country } \\
\text { geographical } \\
\text { region }\end{array}$ & $\begin{array}{c}\text { No. of } \\
\text { samples }\end{array}$ & $\begin{array}{c}\text { No of } \\
\text { samples with } \\
\text { S. aureus }\end{array}$ & $\begin{array}{l}\text { Range of } \\
\text { S. aureus counts } \\
\text { CFU/ml }\end{array}$ & $\begin{array}{l}\text { No. of non- } \\
\text { compliable } \\
\text { samples }\end{array}$ & $\begin{array}{l}\text { Detection of SEs } \\
\text { with SET RPLA }\end{array}$ & $\begin{array}{l}\text { Detection } \\
\text { of SEs with } \\
\text { VIDAS }\end{array}$ \\
\hline 1. Central & 8 & 3 & 190 to 3000 & 1 & 1 strain-SEA & 1 strain \\
\hline 2. East & 20 & 13 & 670 to $>4900$ & 12 & $\begin{array}{c}\text { 1-SEC } \\
\text { 2.-SEA and SEC } \\
\text { 3.-SEA and SEB } \\
\text { 4.SEA }\end{array}$ & 4 strains \\
\hline 3. East & 10 & 9 & 300 to 1300 & 0 & l & l \\
\hline 4. East & 2 & 2 & $>4900$ & 2 & SEB & 1strain \\
\hline 5. West & 13 & 7 & 40 to $>4900$ & 3 & l & l \\
\hline 6. East & 16 & 4 & 20 to 120 & 0 & l & I \\
\hline 7. East & 13 & 6 & 20 to 200 & 0 & 0 & 2 strains \\
\hline 8. Central & 6 & 2 & 10 to 40 & 0 & l & l \\
\hline 9. Central & 26 & 19 & 10 to 100 & 0 & $\begin{array}{l}\text { 1.SEA and SEB } \\
\text { 2.SEA }\end{array}$ & 2 strains \\
\hline 10. East & 3 & 3 & $>4900$ & 3 & I & l \\
\hline 11. East & 4 & 3 & 10 to 120 & 0 & l & l \\
\hline 12. East & 6 & 6 & $>4900$ & 6 & l & l \\
\hline 13. West & 13 & 13 & $>4900$ & 13 & I & l \\
\hline 14. West & 18 & 18 & 60 to $>4900$ & 16 & / & / \\
\hline
\end{tabular}

Table 2. Results for the cheese samples for enumeration of $S$. aureus in cheese samples and ability of the strains for SEs production

\begin{tabular}{|c|c|c|c|c|c|c|}
\hline $\begin{array}{l}\text { No. of dairy facility /type of } \\
\text { cheese sample }\end{array}$ & $\begin{array}{l}\text { No. of } \\
\text { units }\end{array}$ & $\begin{array}{l}\text { Ripening } \\
\text { period }\end{array}$ & $\begin{array}{c}\text { Range of } \\
\text { S. aureus } \\
\text { counts CFU/g }\end{array}$ & $\begin{array}{l}\text { No. of non- } \\
\text { compliable } \\
\text { samples }\end{array}$ & $\begin{array}{l}\text { Detection of } \\
\text { SEs with SET } \\
\text { RPLA }\end{array}$ & $\begin{array}{l}\text { Detection } \\
\text { of SEs with } \\
\text { VIDAS }\end{array}$ \\
\hline 1/White cow cheese & 5 & over 2 months & 0 & l & 1 & 1 \\
\hline 2/White cow cheese & 10 & over 2 months & 0 & l & / & / \\
\hline 3/White cow cheese & 5 & over 1 month & 0 & / & / & l \\
\hline 4/White cow cheese & 5 & over 1 month & 0 & l & / & l \\
\hline 5/White cow cheese & 5 & over 2 months & 0 & I & / & / \\
\hline 6/White cow cheese & 10 & over 2 months & 0 & I & / & / \\
\hline 7/White cow cheese & 5 & 1 month & $40-100$ & 0 & / & 1 \\
\hline 8/White cow cheese & 5 & over 1 month & 0 & / & / & l \\
\hline 9/a-Hard yellow cheese & 10 & over 1 month & 0 & / & l & l \\
\hline 9/b-White cow cheese & 5 & over 1 month & 0 & I & l & I \\
\hline 10/a-Hard yellow cow cheese & 5 & 1 month & $50-1200$ & 2 & SEA & 1 \\
\hline 10/b-Cow bitten cheese (Bieno) & 5 & 3 weeks & $80-8000$ & 3 & SEC & 1 \\
\hline 11/White cow cheese & 5 & 3 weeks & $20-120$ & 0 & SEA & 1 \\
\hline 12/Cow cheese bitten (Bieno) & 5 & 1 month & $100-1400$ & 2 & SEB and SEC & 1 \\
\hline 13/a-White cow cheese & 5 & 2 weeks & $10-200$ & 0 & SEC & 1 \\
\hline 13/b-Sheep cheese & 5 & 2 weeks & $20-1000$ & 2 & SEB & 1 \\
\hline 13/c-Yellow cheese & 5 & 2 weeks & $500-1200$ & 3 & SEC & 1 \\
\hline 14/a-Sheep bitten cheese (Bieno) & 5 & 2 weeks & $20-6000$ & 3 & SEC & 1 \\
\hline 14/b-Sheep bitten cheese & 5 & 3 weeks & $20-3000$ & 2 & SED & 1 \\
\hline
\end{tabular}




\section{DISCUSSION}

The incidence of staphylococcal intoxication is usually underestimated or unreported due to undetectable and mild symptoms leading to misdiagnosis, unreported minor outbreaks, improper specimen collection and improper laboratory testing.

The prevalence of enterotoxicity is reported differently by various authors and countries due to the diversity of bacterial strains and their characteristics. Our findings are in agreement with the report of Ertas et al. (21) for S. aureus counts and with the report of Dzirba - Korpysa W. and Osek J. (22) for the prevalence of enterotoxic strains S. aureus.

All samples in the current study had a lower S. aureus count than the specified limit $\left(>10^{5} \mathrm{CFU} / \mathrm{g}\right.$ in a product) according to Article 1.28 in the previously stated Book of rules (18). They would not be routinely subjected to testing for SEs presence. Nevertheless, some samples of retail cheese had sufficient bacterial counts that under appropriate environmental conditions, could produce sufficient SEs concentration leading to SFP (23).

Despite the wide discrepancy in data on the prevalence of enterotoxigenic $S$. aureus isolates in the literature, studies conducted in Germany, Brazil, Japan and the United States found a prevalence of enterotoxin genes in $S$. aureus isolates ranging from $10 \%$ to $70 \%$ (9). This variability may be due to differences in sampling (severity of clinical manifestation - mastitis), geographic location, laboratory methods and variations in enterotoxin identification methodology. SEC and SEA are most commonly detected in isolates from cow and human samples, respectively. In the current study, 8 strains with SEA enterotoxicity ( $47 \%$ of SET RPLA-positive samples), 7 SEC (41.1\%), 5 SEB (29.4\%), and 1 SED strains (5.8\%) were isolated. Four strains (23.5\%) were able to produce 2 types of SEs (two strains with SEA and SEB, SEA and SEC, SEB and SEC).

In $3(2.3 \%)$ raw cow milk and cheese samples originating from the same dairy, the SET RPLA (SEA to SED) and the VIDAS SET 2 (SEA to SEE) reports were different. This discrepancy could be explained due to the low SE concentration, under the detection limit of the SET RPLA test, or due to the possible presence of SEE strains undetectable by the SET RPLA. Nevertheless, both methods were highly correlated in detecting SEs (9).

\section{CONCLUSION}

The results of our study showed that the prevalence of enterotoxigenic strains of $S$. aureus obtained from different matrices. These results highlight the importance of proper sanitation and hygiene practices, the use of safe raw materials and proper handling of finished products, and the need for further monitoring of the situation with SEs to have safer food and avoid SFP outbreaks. Further efforts should be made in developing methods (PCR) and detection kits (VIDAS technology) that could detect a broader spectrum of SE.

\section{CONFLICT OF INTEREST}

The authors declare that they have no potential conflict of interest with respect to the authorship and/or publication of this article.

\section{ACKNOWLEDGMENTS}

This research was supported by the Faculty of Veterinary Medicine - Skopje, and the authors would like to thank colleagues from the Department of Microbiology of food and feed at the Food Institute for the cooperation and contribution of this study.

\section{AUTHORS' CONTRIBUTIONS}

MRM conceived the study, did the experimental examinations and wrote the manuscript. LjA contributed with the collecting of the raw milk samples. MP, DJ and PS contributed to the study design. PS supervised the study, gave critical revision and contributed to the final version of the manuscript.

\section{REFERENCES}

1. Normanno, G., Firinu, A., Virgilio, S., Mula, G., Dambrosio, A., Poggiu, A., Decastelli, L., et al. (2005). Coagulase-positive staphylococci and Staphylococcus aureus in food products marketed in Italy. Int J Food Microbiol. 98(1): 73-79.

https://doi.org/10.1016/j.ijfoodmicro.2004.05.008 PMid:15617802

2. The European Union summary report on trends and sources of zoonoses, zoonotic agents and foodborne outbreaks in 2010. (EFSA J.), c2012 [cited 2012 March 8]. https://www.efsa.europa.eu/en/efsajournal/pub/2597 
3. Hunt, K., Schelin, J., Rådström, P., Butler, F., Jordan, K. (2012). Classical enterotoxins of coagulase-positive Staphylococcus aureus isolates from raw milk and products for raw milk cheese production in Ireland. Dairy Sci \& Technol. 92, 487-499.

https://doi.org/10.1007/s13594-012-0067-4

4. Schelin, J., Wallin-Carlquist, N., Thorup Cohn, M., Lindqvist, R., Barker, G. C., Rådström, P. (2011). The formation of Staphylococcus aureus enterotoxin in food environments and advances in risk assessment. Virulence 2, 580-592.

https://doi.org/10.4161/viru.2.6.18122

PMid:22030860 PMCid:PMC3260550

5. Loncarevic, S., Jørgensen, H.J., Løvseth, A., Mathisen, T., Rørvik, L.M. (2005). Diversity of Staphylococcus aureus enterotoxin types within single samples of raw milk and raw milk products. J Appl Microbiol. 98, 344-350.

https://doi.org/10.1111/j.1365-2672.2004.02467.x PMid:15659189

6. Samaržija, D., Damjanović, S., Pogačić, T. (2007). S. Aureus in cheese. Mljekarstvo 57(1): 31-48. [in Serbian].

7. Hennekinne, A., Guiller, F., Perelle, S., DE Buyser, M.L., Dragacci, S., Krys, S., Lombard, B. (2006). Interlaboratory validation according to the EN ISO 16140 Standards of the Vidas SET2 detection kit for use in official controls of staphylococcal enterotoxins in milk products. J Appl Microbiol. 102, 1-11. https://doi.org/10.1111/j.1365-2672.2006.03183.x PMid:17448161

8. Morandi, S., Brasca, M., Lodi, R., Brusetti, L., Andrighetto, C., Lombardi, A., (2010). Biochemical profiles, restriction fragment length polymorphism (RFLP), random amplified polymorphic DNA (RAPD) and multilocus variable number tandem repeat analysis (MLVA) for typing Staphylococcus aureus isolated from dairy products. Res Vet Sci. 88, 427-435.

https://doi.org/10.1016/j.rvsc.2009.10.005

PMid:19926103

9. Ossiprandi, M. C., Zerbini, L. (2014). Multiplex PCR and RPLA detection of enterotoxins in Staphylococcus aureus strains isolated from milk, dairy products and human faecal samples. Journal of Advances in Biology 4(1): 312-317.

10. Argudín, M.Á., Mendoza, M.C., Rodicio, M.R. (2010). Food poisoning and Staphylococcus aureus enterotoxins. Toxins 2, 1751-1773.

https://doi.org/10.3390/toxins2071751

PMid:22069659 PMCid:PMC3153270
11. Janstova, B., Necidova, L., Janstova, B., Vorlova, L. (2012). Staphylococcus aureus growth and enterotoxin production in different types of milk. Acta Univ Agric et Silvic Mendel Brun. 60(5): 103-108. https://doi.org/10.11118/actaun201260050103

12. Le-Loir, Y., Baron, F., Gautier, M. (2003). Staphylococcus aureus and food poisoning. Genet Mol Res. 2, 63-76.

13. Little, C.L., Rhoades, J.R., Sagoo, S.K., Harris, J., Greenwood, M., Mithani, V., Grant, K., McLauchlin, J. (2008). Microbiological quality of retail cheeses made from raw, thermized or pasteurized milk in the UK. Food Microbiol. 25, 304-312.

https://doi.org/10.1016/j.fm.2007.10.007

PMid:18206773

14. DeVita, M.D., Wadhera, R.K., Theis, M.L., Ingham, S.C., (2007). Assessing the potential of Streptococcus pyogenes and Staphylococcus aureus transfer to foods and customers via a survey of hands, hand-contact surfaces and food-contact surfaces at foodservice facilities. J Foodservice. 18, 76-79.

https://doi.org/10.1111/j.1745-4506.2007.00049.x

15. Jablonski, L.M., Bohach, G. (2001). Staphylococcus aureus. In: Doyle M.P., Beuchat, L.R., Montville, T.J. (Eds.), Food microbiology: Fundamentals and Frontiers (pp. 411-434). Washington: ASM Press.

16. EN ISO 6888: 1999. [Internet]. Microbiology of food and feed - Horizontal method for detection of coagulase positive staphylococci (Staphylococcus aureus and other spp.)-Part 1: Technique using Baird-Parker agar medium.

https://www.iso.org/standard/23036.html

17. Official Gazette of R.M. Book of Rules from 21.02.2012, concerning Requirements for the number of somatic cells and the number of microorganisms in raw milk, Article 19, Off. G. of R.M. 26/2012, p. 25.

http://www.slvesnik.com.mk/Issues/4001C55710C11D4C8B42458E7AE73B7C.pdf

18. Official Gazette of R.M. Book of rules for the special requirements for the microbiology criteria for food safety, Article 2.2.4 from 15.07.2013, Off. G. of R.M. 100/2013, p. 36.

http://www.slvesnik.com.mk/Issues/f12f6d7db7aa4493a5d3ab7be017f987.pdf

19. Su, S.B., Wang, Y.L., Chiu, S.I., Tsai, J.L., Chou, C.I. (2005). Establishing the use of Real-time PCR for staphylococcal enterotoxin. Epidemiology Bulletin 21(12): 387-395.

20. Vernozy-Rozand, C., Mazuy-Chruchaudet, C., Bavai, Y.R. (2004). Comparison of three immunological methods for detecting staphylococcal enterotoxins from food. Lett Appl Microbiol. 39, 490-495. https://doi.org/10.1111/j.1472-765X.2004.01602.x PMid:15548300 
21. Ertas, N., Gonulalan, Z., Yildrim, Y., Kum, E. (2010). Detection of Staphylococcus aureus enterotoxins in sheep cheese and dairy desserts by multiplex PCR technique. Int J Food Microbiol. 142(1-2): 74-77.

https://doi.org/10.1016/j.ijfoodmicro.2010.06.002 PMid:20573416

22. Korpysa-Dzirba, W., Osek, J. (2014). Detection of classical genes and enterotoxins of Staphylococcus aureus isolated from raw milk in the south-east region of Poland. Bull Vet Inst Pulawy. 58, 559-561. https://doi.org/10.2478/bvip-2014-0086
23. Das Dores, M.T., Dias, R.S., Arcuri, E.F., da Nobrega, J.E., de Luces, C.L., Ferreira, F. (2013). Enterotoxigenic potential of Staphylococcus aureus isolated from Artisan Minas cheese from the Serra da Canastra - MG. Brazil Food Sci Technol Campinas. 33(2): 271-275.

https://doi.org/10.1590/S0101-20612013005000033

Please cite this article as: Ratkova Manovska M., Prodanov M., Angelovski Lj., Jankuloski D., Sekulovski P. Prevalence of the enterotoxigenic Staphylococcus aureus strains isolated from raw milk and cheese produced in North Macedonia. Mac Vet Rev 2021; 44 (1): 71-77. https://doi.org/10.2478/macvetrev-2021-0014 